\title{
Chemistry of feldspars in the Ilímaussaq augite syenite with additional data on some other minerals
}

\author{
Lotte Melchior Larsen
}

The feldspars of the augite syenite have been described by Ussing (1912, p. 188), Hamilton (1964) and Ferguson (1964, 1970, pp. 49-51). These authors used optical and X-ray methods giving only crude clues to chemistry. However, Hamilton (1964, pp. 28-29) noted the scarce occurrence of corroded oligoclase cores, and Ferguson (1970) noted that the $\mathrm{Ab} / \mathrm{Or}$ ratio is higher in feldspar from the augite syenite than in feldspar from the agpaitic rocks. Below are reported the results of a microprobe reconnaissance study of feldspars from the augite syenite, together with microprobe data on some other minerals. The two samples selected are the same as used in a previous investigation of the mafic minerals (Larsen, 1976). They represent the outermost chilled facies (U-106) and the innermost facies, bordering on the agpaites (150722). Since the augite syenite has apparently congealed inwards from the sides these samples should bracket the compositional range of the minerals present. The analytical technique was as described by Reed \& Ware (1975) with the addition that $\mathrm{BaO}$ in the feldspars was calculated from the apparent $\mathrm{TiO}_{2}$ according to the empiric relation $\mathrm{BaO}=1.9 \times{ }^{\prime} \mathrm{TiO}_{2}$ '.

\section{Feldspar}

Optically the mineral is mostly clear, untwinned and homogeneous-looking, but wavy extinctions and incipient exsolution along cracks and grain boundaries testify to the cryptoto microperthitic nature of the feldspar found by previous workers (op. cit.). In the chilled facies several feldspar grains enclose untwinned cores with slightly different extinction, sometimes with irregular and sometimes with straight-line boundaries towards the mantling

Fig. 1. Feldspar in chilled augite syenite U-106. Core of oligoclase with relatively well-defined outline, surrounded by alkali feldspar.

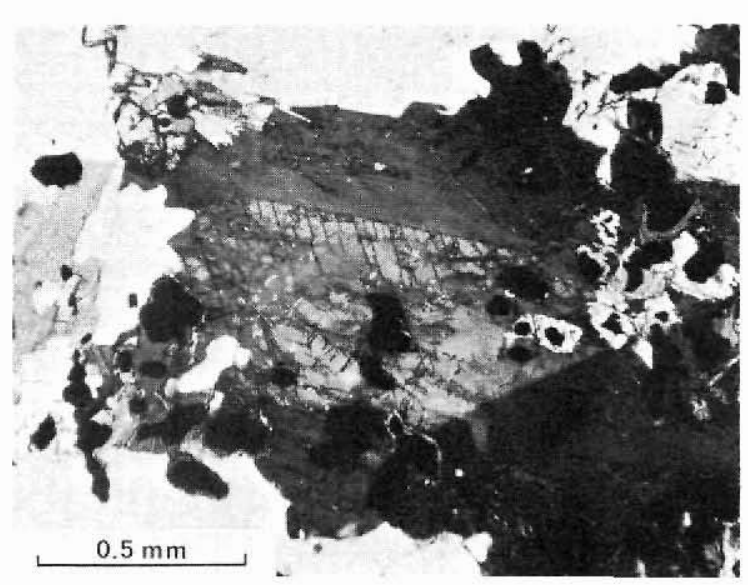


Table 1. Representative analyses of feldspars from the Ilimaussaq augite syenite

\begin{tabular}{|c|c|c|c|c|c|c|}
\hline \multirow{2}{*}{$\frac{\mathrm{GGU} \text { no. }}{\mathrm{SiO}_{2}}$} & \multicolumn{4}{|c|}{ U-106 } & \multicolumn{2}{|c|}{150722} \\
\hline & 62.35 & 64.55 & 64.46 & 64.03 & 65.66 & 65.79 \\
\hline $\mathrm{Al}_{2} \mathrm{O}_{3}$ & 23.44 & 22.22 & 20.78 & 20.06 & 19.87 & 19.92 \\
\hline $\mathrm{BaO}$ & 0.68 & 0.34 & 1.25 & 0.48 & 0.21 & 0.00 \\
\hline $\mathrm{CaO}$ & 4.19 & 2.55 & 1.29 & 1.10 & 0.75 & 0.53 \\
\hline $\mathrm{Na}_{2} \mathrm{O}$ & 8.85 & 9.48 & 5.69 & 5.41 & 6.98 & 6.37 \\
\hline \multirow[t]{2}{*}{$\mathrm{K}_{2} \mathrm{O}$} & 0.76 & 1.21 & 7.13 & 8.07 & 6.43 & 7.43 \\
\hline & 100.27 & 100.35 & 100.60 & 99.15 & 99.90 & 100.04 \\
\hline \multicolumn{7}{|c|}{ Cations } \\
\hline $\mathrm{Si}$ & 11.086 & 11.398 & 11.614 & 11.689 & 11.790 & 11.809 \\
\hline Al & 4.913 & 4.626 & 4.414 & 4.317 & 4.206 & 4.214 \\
\hline $\mathrm{Ba}$ & 0.047 & 0.024 & 0.088 & 0.034 & 0.015 & 0.000 \\
\hline $\mathrm{Ca}$ & 0.798 & 0.482 & 0.249 & 0.215 & 0.144 & 0.101 \\
\hline $\mathrm{Na}$ & 3.051 & 3.246 & 1.988 & 1.915 & 2.430 & 2.219 \\
\hline \multirow[t]{2}{*}{ K } & 0.172 & 0.273 & 1.639 & 1.879 & 1.473 & 1.701 \\
\hline & 20.067 & 20.049 & 19.992 & 20.049 & 20.058 & 20.044 \\
\hline An & 19.6 & 12.0 & 6.3 & 5.3 & 3.5 & 2.5 \\
\hline$A b$ & 75.0 & 80.6 & 50.2 & 47.4 & 59.8 & 55.2 \\
\hline or & 4.2 & 6.8 & 41.3 & 46.5 & 36.3 & 42.3 \\
\hline $\mathrm{Cn}_{\mathrm{n}}$ & 1.2 & 0.6 & 2.2 & 0.8 & 0.4 & 0.0 \\
\hline
\end{tabular}

feldspar (fig. 1). Such cores are not found in the innermost facies. In the sample from the innermost facies a $3 \mathrm{~mm}$ broad zone runs across the section and shows signs of late alteration by a volatile-bearing phase, giving rise to coarse, incoherently exsolved patches of albite in the feldspar.

The feldspar analyses were performed with the electron beam defocussed to approximately 20 microns. Representative chemical analyses are listed in Table 1, and all results are plotted in fig. 2 .

The feldspar in the chilled facies (U-106) spans a relatively large compositional range, from oligoclase $\mathrm{An}_{20} \mathrm{Ab}_{76} \mathrm{Or}_{4}$ to sodic $\mathrm{K}$-feldspar $\mathrm{An}_{3.5} \mathrm{Ab}_{43.5} \mathrm{Or}_{53}$. All analyses with $\mathrm{An}$ $\geqq 10 \%$ are from the cores mentioned above, and the gap at $\mathrm{Or}_{20}-\mathrm{Or}_{30}$ is real and represents the break between the cores and the broad margins. The cores are volumetrically subordinate and are overrepresented in the number of dots in fig. 2. The main feldspar is of composition $\mathrm{An}_{4-9} \mathrm{Ab}_{47-61} \mathrm{Or}_{32-48}$ and thus straddles the boundary at $\mathrm{Or}_{37}$ between anorthoclase and $\mathrm{K}$-feldspar. The analysis of a bulk feldspar separate from chilled Ilímaussaq augite syenite given by Upton (1964, p. 68) as $\mathrm{An}_{8.5} \mathrm{Ab}_{58.5} \mathrm{Or}_{32} \mathrm{Cn}_{1}$ is in excellent agreement with the microprobe results (fig. 2). 

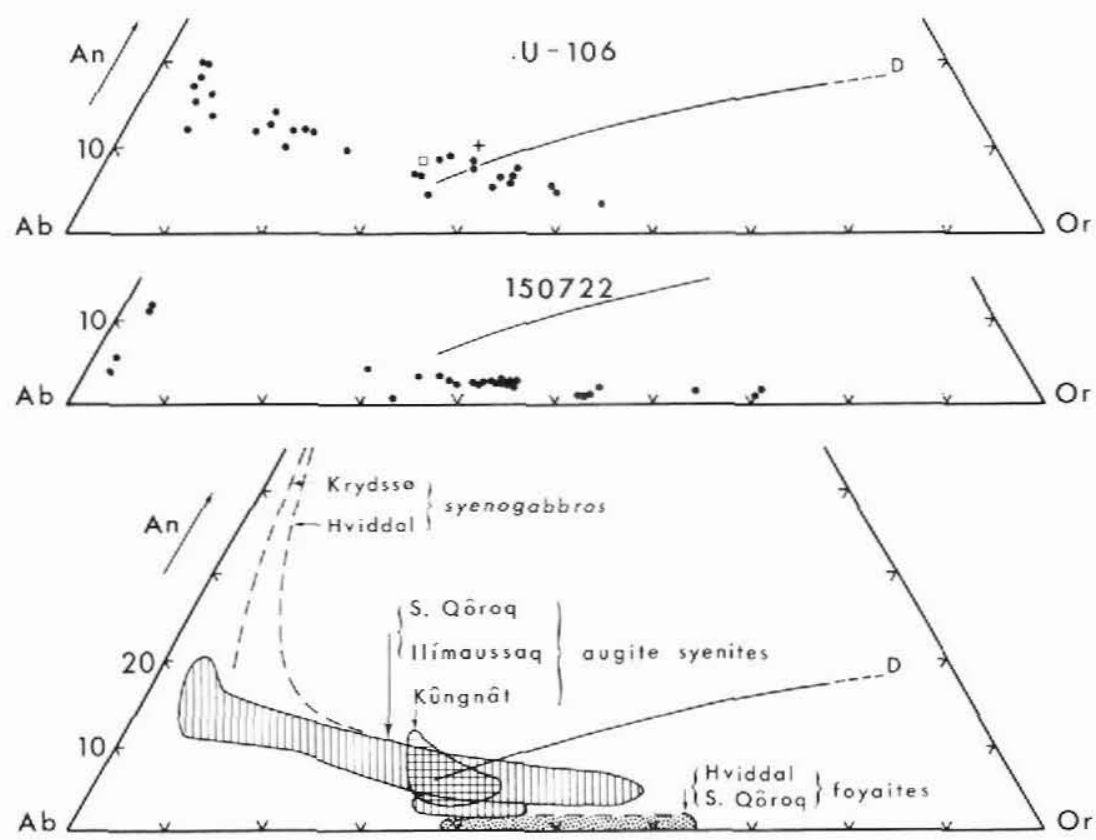

Fig. 2. Feldspar analyses from the Ilímaussaq augite syenite. U-106: chilled facies. Open square $=$ bulk feldspar analysis from the chilled facies (sample 40527, Upton, 1964). Cross $=$ normative feldspar composition of U-106. 150722: innermost facies of augite syenite, bordering on the agpaites.

Comparative Gardar feldspar trends from Upton $(1960,1964)$ and Stephenson $(1976)$. The feldspar cotectic curve, D, is taken from Tuttle \& Bowen (1958).

In the innermost facies (150722), the common feldspar has a much more restricted range in composition, namely $\mathrm{An}_{2-4} \mathrm{Ab}_{52-63} \mathrm{Or}_{34-45}$. The coarsely exsolved $\mathrm{K}$-feldspar in the volatile-influenced patch enlarges the compositional range to $\mathrm{An}_{0.5-4} \mathrm{Ab}_{28-67} \mathrm{Or}_{24-70^{-}}$. The exsolved plagioclase feldspar, $\mathrm{An}_{4-12} \mathrm{Ab}_{85-94} \mathrm{Or}_{2-3}$, is $\mathrm{Ca}$-enriched compared to the remaining feldspar.

Barium is a significant minor element. The feldspars from the chilled facies (U-106) have from 0.3 to $1.3 \mathrm{wt} \% \mathrm{BaO}$, corresponding to 0.5 to $2.3 \mathrm{~mole} \%$ celsian. There is no obvious relation between barium and calcium content (fig. 3). The feldspars from the innermost facies (150722) have much lower barium contents, from below the lower limit of detection (approx. $0.15 \%$ ) to $0.3 \% \mathrm{BaO}$. The $\mathrm{Fe}_{2} \mathrm{O}_{3}$ content is in nearly all cases below the detection limit (approx. 0.15\%).

\section{Comparisons}

The feldspar trend in the Ilímaussaq chilled facies is identical with the trend established by Stephenson (1976) for a mafic band in the augite syenite unit SS4b in the South Qôroq Centre of the Igaliko complex. Also the compositional gap at $\mathrm{Or}_{20}-\mathrm{Or}_{30}$ is common to the two. Further, the normal facies of the same rock unit (SS4b) has feldspar compositions very similar to those of the inner facies of the Ilímaussaq augite syenite. Comparable feldspar 


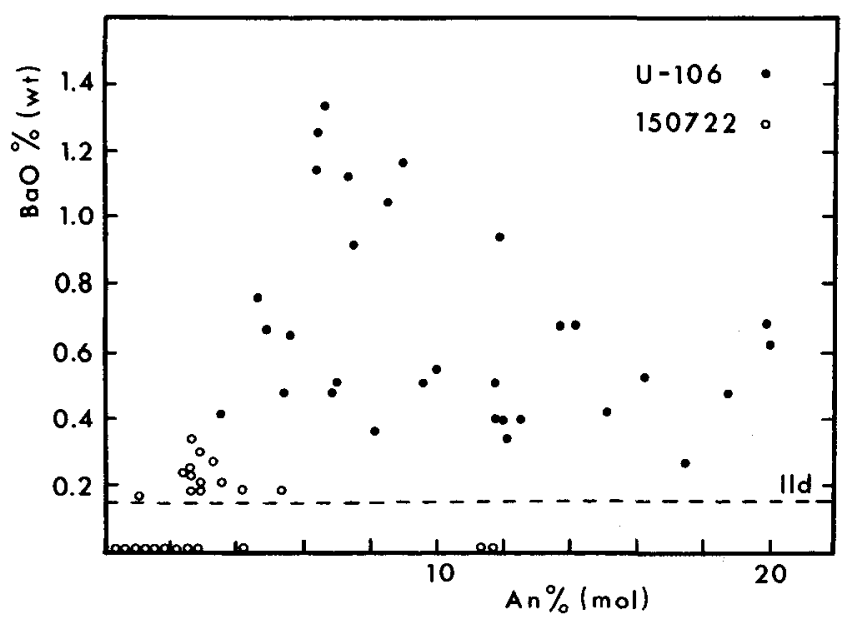

Fig. 3. Barium content versus anorthite component for feldspars from the Ilímaussaq augite syenite.

lld = lower limit of detection.

trends are also found in the Oslo larvikites (Oftedahl, 1948; Muir \& Smith, 1956). These authors described corroded cores of acid plagioclase in alkali feldspar, and the feldspar diagram for the Oslo province plutonic rocks given by Oftedahl $(1948$, p. 53) also has a compositional gap at $\mathrm{Or}_{20-30}$. Upton (1960) gave bulk feldspar analyses for augite syenites from the Kûngnât complex in the range $\mathrm{An}_{3-11} \mathrm{Ab}_{53-62} \mathrm{Or}_{30-42}$. He inferred (p. 54) that more Ca-rich compositions would be present, and it is extremely likely that microprobe investigation of these rocks would yield feldspar trends similar to those for Ilímaussaq and the South Qôroq Centre.

\section{Discussion of feldspar crystallisation}

As pointed out by Upton (1964), and illustrated here in fig. 2, augite syenite feldspars occupy a compositional range between the plagioclases of syenogabbros and the alkali feldspars of foyaites. The liquids would have been lying above the solvus, and on the plagioclase side of, but fairly near to, the feldspar cotectic curve (in fig. 2 this is the case for both the bulk feldspar and the normative feldspar of the chilled facies, U-106), thus precipitating plagioclase as the first feldspar phase. The liquid quite rapidly reached the feldspar cotectic curve, and large amounts of alkali feldspar started crystallising. By equilibrium crystallisation the plagioclase would have changed composition continuously through the anorthoclase compositional area until it merged into the alkali feldspar composition at the critical solution point. Fractionation arrested this process, leaving cores of more or less equilibrated plagioclase and anorthoclase enclosed in alkali feldspar. This crystallisation scheme is as described by Tuttle \& Bowen (1958, pp. 133-134, liquid X). (Also cited in Deer et al., 1963).

Resorbed cores of presumed plagioclase have been observed occasionally in augite syenite samples away from the chilled facies. The innermost facies (150722), however, does not have them. Its single primary alkali feldspar has a restricted compositional range, and the liquid may have been on the cotectic or may even have left it again. 


\section{Feldspars in the Ilimaussaq foyaite}

Microprobe integration of the very coarsely exsolved feldspars from the later formed foyaite of the Ilímaussaq intrusion was attempted but gave erratic results with regard to the $\mathrm{Na} / \mathrm{K}$ ratio. However, it confirmed that the foyaite feldspars are essentially Ca-free, in agreement with the foyaite feldspars from the South Qôroq Centre (Stephenson, 1976) which probably serve well as indicators of the original composition of feldspar from the Ilímaussaq foyaites.

\section{Other minerals in the augite syenite}

Nepheline occurs interstitially in the innermost facies; an analysis is presented in Table 2. The temperature range indicated by the three rather uniform nepheline analyses is 800 $850^{\circ} \mathrm{C}$ (Hamilton, 1961). Stephenson (1976) found similar nephelines in the augite syenite SS4b of the South Qôroq Centre. These temperatures seem to be magmatic and indicate that the nephelines have not, or nearly not, re-equilibrated during cooling.

Magnetite. All the primary titanomagnetite grains are oxidised and contain ilmenite lamellae. Broad beam analyses show 24-26.5\% $\mathrm{TiO}_{2}$ (Table 2). Primary ilmenite is not present.

Table 2. Other minerals from the Ilimaussaq augite syenite

\begin{tabular}{|c|c|c|c|c|c|c|c|c|c|c|}
\hline \multirow{3}{*}{$\frac{\mathrm{GGU} \text { no. }}{\mathrm{SiO}_{2}}$} & \multirow{2}{*}{$\frac{\text { Nepheline }}{150722}$} & \multirow{2}{*}{\multicolumn{2}{|c|}{$\frac{\text { Magnetite }}{\mathrm{U}-106}$}} & & \multicolumn{4}{|c|}{ Amphibole } & \multicolumn{2}{|c|}{ Biotite } \\
\hline & & & & & & $\mathrm{U}-106$ & 150722 & 150722 & $\mathrm{U}-106$ & 150722 \\
\hline & 45.97 & $\mathrm{TiO}_{2}$ & 26.25 & & $\mathrm{SiO}_{2}$ & 40.05 & 38.74 & 40.28 & 35.01 & 33.14 \\
\hline $\mathrm{Al}_{2} \mathrm{O}_{3}$ & 32.84 & $\mathrm{Al}_{2} \mathrm{O}_{3}$ & 1.87 & & $\mathrm{TiO}_{2}$ & 3.73 & 2.03 & 0.15 & 6.04 & 0.00 \\
\hline $\mathrm{CaO}$ & 0.52 & $\mathrm{Fe}_{2} \mathrm{O}_{3}$ & 16.38 & & $\mathrm{Al}_{2} \mathrm{O}_{3}$ & 10.24 & 10.89 & 8.49 & 12.66 & 14.51 \\
\hline $\mathrm{Na}_{2} \mathrm{O}$ & 16.09 & $F \in 0$ & 53.48 & & $\mathrm{Fe}_{2} \mathrm{O}_{3}$ & 0.00 & 1.13 & 4.18 & - & - \\
\hline \multirow{3}{*}{$\mathrm{K}_{2} \mathrm{O}$} & 4.79 & Mno & 7.00 & & $\mathrm{FeO}$ & 20.41 & 26.23 & 25.59 & 21.97 & 32.39 \\
\hline & 100.21 & $\mathrm{MgO}$ & 0.66 & & $\mathrm{mnO}$ & 0.23 & 0.40 & 0.47 & 0.00 & 0.29 \\
\hline & & $\mathrm{CaO}$ & 0.18 & & $\mathrm{MgO}$ & 7.36 & 3.22 & 3.55 & 9.13 & 4.39 \\
\hline Cations & & & $\overline{99.82}$ & & $\mathrm{CaO}$ & 10.92 & 10.47 & 10.16 & 0.12 & 0.18 \\
\hline Si & 8.693 & $\mathrm{FeOT}$ & 68.22 & & $\mathrm{Na}_{2} \mathrm{O}$ & 2.72 & 2.99 & 3.12 & 0.36 & 0.70 \\
\hline Al & 7.320 & & & & $\mathrm{k}_{2} \mathrm{O}$ & 1.61 & 1.73 & 1.80 & 9.00 & 8.33 \\
\hline $\mathrm{Ca}$ & 0.106 & Cations & & & & $\overline{97.27}$ & 97.83 & 97.79 & 94.29 & 93.93 \\
\hline $\mathrm{Na}$ & 5.901 & $\mathrm{Ti}$ & 5.848 & & PeOp & 20.41 & 27.25 & 29.35 & - & - \\
\hline \multirow[t]{3}{*}{$\mathrm{K}$} & 1.154 & Al & 0.653 & & Cations & & & & & \\
\hline & $\overline{23 . \overline{174}}$ & $\mathrm{Fe}^{+3}$ & 3.652 & & Si & 6.261 & 6.215 & 6.494 & 5.514 & 5.524 \\
\hline & & $\mathrm{Fe}^{+2}$ & 13.248 & $2\}$. & $A I I V$ & 1.739 & 1.785 & 1.506 & & \\
\hline $\mathrm{Ne}$ & 75.8 & $\mathrm{Mn}$ & 0.25 .1 & & AI VI & 0.148 & 0.275 & 0.108 & 2.350 & 2.850 \\
\hline $\mathrm{Ks}$ & 16.5 & $\mathrm{Mg}$ & 0.291 & & $\mathrm{Ti}$ & 0.439 & 0.245 & 0.018 & 0.716 & 0.000 \\
\hline \multirow[t]{8}{*}{$Q z$} & 7.7 & $\mathrm{Ca}$ & 0.057 & $\mathrm{Y}$ & $F e^{+3}$ & 0.000 & 0.137 & 0.507 & - & - \\
\hline & & & & & $\mathrm{Fe}+2$ & 2.668 & 3.519 & 3.451 & 2.893 & 4.515 \\
\hline & & usp $\%$ & 75.2 & & $M_{n}$ & 0.030 & 0.054 & 0.064 & 0.000 & 0.040 \\
\hline & & & & & $\mathrm{Mg}_{\mathrm{g}}$ & 9.715 & 0.770 & 0.853 & 2.144 & 1.092 \\
\hline & & & & & $\mathrm{Ca}$ & 1.829 & 1.800 & 1.755 & 0.020 & 0.033 \\
\hline & & & & $x\{$ & $\mathrm{Na}$ & 0.824 & 0.930 & 0.975 & 0.110 & 0.226 \\
\hline & & & & & $K$ & 0.321 & 0.354 & 0.370 & 1.808 & 1.770 \\
\hline & & & & & & $\overline{15.974}$ & $\overline{16.084}$ & $\overline{16.101}$ & $\overline{15.555}$ & $\overline{16.050}$ \\
\hline
\end{tabular}

Bases for calculations: Nepheline: 32 oxygens. Magnetite: 24 cations and 32 oxygens. Amphibole: 13 Y 7 cations and 23 oxygens. Biotite: 22 orygens. 
Olivine, pyroxene and amphibole. The analyses of these phases are in very good agreement with the results obtained with a crystal spectrometer microprobe. Specifically, the compositional ranges found in olivine and pyroxene are the same as those previously reported (Larsen, 1976). The homogeneity of the red-brown interstitial amphibole in the chilled facies (U-106) was confirmed. Its name is titanian ferroan pargasitic hornblende (approaching kaersutite) according to Leake (1978). In the innermost facies (150722) the common amphibole is brownish to greenish (titanian) ferro-pargasite occurring in individual interstitial grains and as patchy replacements of the pyroxene. In the previously described, volatileinfluenced zone a green to bluish green Ti-free hastingsitic to ferro-edenitic hornblende is found rimming a fayalite grain. Analyses of the various amphibole types are given in Table 2. They have all been recalculated on a cationic basis, with $Z+Y=13$. This calculation procedure illustrates the low oxidation state of the amphiboles previously inferred (Larsen, 1976) and also indicates a certain rise in oxidation state with crystallisation. It is due to the low oxidation state that the early amphiboles are pargasitic $\left(\mathrm{Al}_{\mathrm{VI}}>\mathrm{Fe}^{3+}\right)$ and not hastingsitic $\left(\mathrm{Fe}^{3+}>\mathrm{Al} \mathrm{VI}\right)$.

Biotite. Red-brown titan-biotite occurs commonly as radiating fringes around titanomagnetite grains. Grass-green Ti-free biotite is found intergrown with the above mentioned, bluish green amphibole rim on fayalite in the volatile-influenced zone. Analyses of both types are shown in Table 2. While the oxidation state of the brown biotite is uncertain, the green biotite has a cation sum larger than 16 , indicating that some $\mathrm{Fe}^{3+}$ is definitely present.

The green Ti-free amphibole and biotite are thought to be subsolidus recrystallisation products formed during volatile percolation through the rock. They illustrate the difference between the results of this type of crystallisation and the high-temperature magmatic intercumulus crystallisation.

Acknowledgement. The analyses were carried out during the tenure of a visiting fellowship at Research School of Earth Sciences, Australian National University, Canberra. Dr. N. G. Ware is thanked for technical assistance with the probe work.

\section{References}

Deer, W. A., Howie, R. A. \& Zussman, J. 1963: Rock-forming minerals, 4, Framework Silicates. London: Longmans, $435 \mathrm{pp}$.

Ferguson, J. 1964: Geology of the Ilímaussaq alkaline intrusion, South Greenland. Description of map and structure. Bull. Grønlands geol. Unders. 39 (also Meddr Grønland 172,4) $82 \mathrm{pp}$.

Ferguson, J. 1970: The significance of the kakortokite in the evolution of the Ilímaussaq intrusion, South Greenland. Bull. Grønlands geol. Unders. 89 (also Meddr Grønland 186,5) 193 pp.

Hamilton, D. L. 1961: Nephelines as crystallisation temperature indicators. J. Geol. 69, 321-329.

Hamilton, E. I. 1964: The geochemistry of the northern part of the Ilimaussaq intrusion, S.W. Greenland. Bull. Grønlands geol. Unders. 42, (also Meddr Grønland 162,10) 104 pp.

Larsen, L. M. 1976: Clinopyroxenes and coexisting mafic minerals from the alkaline Ilímaussaq intrusion, South Greenland. J. Petrol. 17, 258-290.

Leake, B. E. 1978: Nomenclature of amphiboles. Compiled for I.M.A. subcommittee on amphiboles. Min. Mag. 42, 533-563.

Muir, I. D. \& Smith, J. V. 1956: Crystallisation of feldspars in larvikites. Zeit. Krist. 107, 182-195. 
Oftedahl, C. 1948: Studies on the igneous rock complex of the Oslo region. IX. The feldspars. Skr. Norske Vid. Akad. I. Mat.-Naturv. K1. 3, 71 pp.

Reed, S. J. B. \& Ware, N. G. 1975: Quantitative electron microprobe analysis of silicates using energy-dispersive X-ray spectrometry. J. Petrol. 16, 499-519.

Stephenson, D. 1976: The South Qôroq Centre nepheline syenites, South Greenland. Petrology, felsic mineralogy and petrogenesis. Bull. Grønlands geol. Unders. 118, $55 \mathrm{pp}$.

Tuttle, O. F. \& Bowen, N. L. 1958: Origin of granite in the light of experimental studies in the system $\mathrm{NaAlSi}_{3} \mathrm{O}_{8}-\mathrm{KalSi}_{3} \mathrm{O}_{8}-\mathrm{SiO}_{2}-\mathrm{H}_{2} \mathrm{O}$. Mem. Geol. Soc. Amer. 74, 153 pp.

Upton, B. G. J. 1960: The alkaline igneous complex of Kûngnât Fjeid, South Greenland. Bull. Grønlands geol. Unders. 27, (also Meddr Grønland 123,4) 145 pp.

Upton, B. G. J. 1964: The geology of Tugtutôq and neighbouring islands, South Greenland. Part III: Olivine gabbros, syenogabbros and anorthosites; and Part IV: The nepheline syenites of the Hviddal composite dyke. Bull. Grønlands geol. Unders. 48, (also Meddr Grønland 169,3) 80 pp.

Ussing, N. V. 1912: Geology of the country around Julianehaab, Greenland. Meddr Grønland 38, 376 pp.

Grønlands Geologiske Undersøgelse $\emptyset$ ster Voldgade 10, DK-1350 Copenhagen $\mathrm{K}$. 